\title{
KONFESYJNA NAUKA RELIGII W PUBLICZNEJ SZKOLE ZSEKULARYZOWANEGO SPOEECZEŃSTWA
}

Już sam tytuł referatu wskazuje, że chodzi tutaj o bulwersującą sprawę. Konfesjonalna nauka religii bowiem — mówiąc krótko w idealnym znaczeniu — polega na podporządkowaniu jej nauce Kościoła oraz przekazywaniu jej przez nauczyciela, który ma za sobą studia teologiczne i posiada misję kanoniczną. Adresatami zaś są uczniowie ochrzczeni w Kościele katolickim, a ich rodzice z kolei tego sobie życzą. Do takich należy obecnie w RFN około 90 \% katolickiej ludności.

Publiczna szkoła jest z reguły szkołą państwową, w której katolicy, ewangelicy, muzułmanie, ludzie religijnie indyferentni oraz ateiści w równym stopniu korzystają z ojczystego prawa. Jest to „szkoła dla wszystkich”. Gdy chodzi o naukę religii, to społeczność klasowa musi być rozdzielana. Dzieje się to nie bez trudności, ale są już pod tym względem pewne tradycje i, jak dotąd, były na ogół akceptowane. Nowość naszej sytuacji i jej kryzysowe wyostrzenie wynika $\mathrm{z}$ trzeciego hasła zawartego w tytule referatu: zsekularyzowanego społeczeństwa. Na cóż zdaje się nauka religii w szkole, jeśli rodzice, którzy posyłają na nią dzieci i płacą podatek na Kościół, jednak sami są niepraktykującymi tzn. nie modlą się, nie biorą udziału we Mszy św., ignorują naukę Kościoła, a wiarę traktują jako coś zbytecznego, słowem są religijnie idyferentnymi i dystansują się od spraw kościelnych.

W wielkich miastach Niemiec Zachodnich na naukę religii uczęszcza wprawdzie 80 do $90 \%$ katolickich dzieci, ale tylko około $10 \%$ spośród nich bierze udział w praktykach religijnych. Dla większości wiara utraciła wszelki związek z życiem; stała się czymś nieaktualnym. W tym tkwi właśnie jądro problemu, na który chciałbym zwrócić naszą uwagę. Nie wiem, czy z tego będziecie mogli odnieść coś dla siebie w waszej sytuacji i dla przyszłości nauki religii w Polsce. Mam jednak nadzieję, że ten referat przyczyni się do pewnego zrozumienia

* Referat wygloszony po niemiecku w Papieskiej Akademii Teologicznej w Krakowie 9 V 1989 roku. 
niektórych, być może obco wyglądających dla was fenomenów i zdarzeń, jakie występują w katolickim Kościele Republiki Federalnej Niemiec.

\section{Uwarunkowania historyczne}

Dzisiejsza sytuacja ma swoje uwarunkowanie historyczne. Uwarunkowanie dalsze stanowi konsekwencję podziału Kościoła na różne wyznania w czasie reformacji i kontrreformacji. Organizacja szkolnej nauki religii rozpoczyna się właśnie w 16 wieku, ale od samego początku oddzielnie pod względem wyznaniowym. Ponieważ z reguły terytoria katolickie i ewangelickie były oddzielone, toteż pod względem wyznaniowym zarówno wspólnoty kościelne, jak i szkolne, miały charakter homogeniczny.

Konfesyjna nauka religii służyła refleksji nad tym, co było religijnie praktykowane. Naukę religii strukturyzował katechizm bądź ewangelicki, bądź też katolicki. Służył po prostu pojęciowemu wyjaśnianiu powszechnie wokół przeżywanej wiary. Różnica między jednym a drugim wyznaniem prowadziła do tego, że pojęcia, definicje, wyliczanki w połączeniu z nauczaniem pamięciowym, kształtowały konfesyjny charakter nauki religii.

Bliższe uwarunkowania dzisiejszej sytuacji wypływa z okresu Oświecenia, kiedy to wprowadzono powszechny obowiązek szkolny (Prusy 1763; Bawaria 1802). Państwo przyjęło wtedy odpowiedzialność za system nauczania $\mathrm{z}$ nauką religii włącznie. Kościół zachował w swoich rękach to, co dotyczyło treści nauki religii, a proboszcz danego miejsca pełnił nawet rolę przełożonego w stosunku do nauczyciela; sprawował „duszpasterski nadzór”, który wśród nauczycieli skądinąd nawet wierzących prowadził często do antyklerykalnych resentymentów. Ta „opieka” nad nauczycielami została zniesiona dopiero w roku 1919.

W czasie Oświecenia po raz pierwszy zakwestionowano naukę religii jako domenę kościelno-konfesjonalną. Symptomatyczna jest już sama zmiana tradycyjnego słowa „katechizm” na: nauka religii; odpowiadająca jej dyscyplina naukowa przestała już być odtąd katechetyką, stała się pedagogiką religijną. Prądy oświeceniowe były mocno przesiąknięte ideą tolerancji. Wyznaniowe kontrowersje, a nawet w ogóle dogmatyczne twierdzenia, uchodziły za coś skostniałego.

Sakramenty, ryty, sprawy specyficznie kościelno-instytucjonalne - to wszystko miało ustąpić na rzecz „religii naturalnej” i wychowania moralnego, wspólnego dla wszystkich. Na terenach wyznaniowo zróżnicowanych poczyniono próby, aby w szkołach, tak zwanych symultanach, wprowadzić taki wspólny program religii dla wszystkich uczniów. Ze względu jednak na opór rodziców i sprzeciw Kościoła spełzło to na niczym. Wprawdzie terminy nauka religii i pedagogika religijna zostały przez Kościół zaakceptowane, ale wbrew programom oświeceniowym, zrównano je po prostu z katechezą w tra- 
dycyjnym tego słowa znaczeniu. I tak to zostało do dziś. Moja dziedzina, pedagogika religijna, na uniwersytecie nie jest związana z czymś w rodzaju „naturalnych" nauk religijnych, lecz jest podporządkowana teologii. Jej głównym przedmiotem nie jest religia jako fenomen antropologiczny, lecz przede wszystkim wiara, jaką żyje Kościól, świętuje i przepowiada. Kościelne związki ze szkołą mają także swoją odwrotną stronę, która stopniowo zaczęla się ujawniać jako zjawisko ujemne.

Po pierwsze, od czasów Oświecenia nauczanie wiary stało się czymś na równi z nauczaniem szkolnych przedmiotów. Nauczać wiary oznacza odtąd nie tyle wychowywać chrześcijanina, ile przekazywać mu pewną ilość religijnej wiedzy.

Po drugie, rodzice, jak i całe parafie, zaczęły stopniowo zatracać świadomość odpowiedzialności za przekaz wiary. Obowiązek ten po prostu został przerzucony na społeczne instytucje i delegowanych do tych zadań profesjonalistów. Religię zaczęto teraz w większym stopniu traktować jako sprawę zawodową.

Dziewiętnastowieczna neoscholastyka nie dostrzegała tych braków, ale przeciwnie, przejęła to natchnienie i wyraźnie je hołubiła. W XX wieku jednak pojawily się nowe siły dążące do odnowy tych koncepcji i do przezwyciężenia wspomnianych braków, mianowicie materialno-kerygmatyczna odnowa, nauczanie religii na sposób przepowiadania itd. Z kolei jednak w tym kontekście uświadomiono sobie dylemat: Jakże to? „Przepowiadanie” na tej samej płaszczyźnie, co sport i chemia? Pomiędzy dwoma dzwonkami w odstępach 45 minutowych, no i ocenami na świadectwie? Jak to razem może się godzić? A może nauka religii stanowi rzeczywiście coś nadzwyczajnego w publicznej szkole i jest „całkiem różna” od innych przedmiotów? Ta rozbieżność wynika $\mathrm{z}$ jednej strony $\mathrm{z}$ istoty chrześcijańskiego orędzia, a $\mathrm{z}$ drugiej strony $\mathrm{z}$ ustawodawstwa szkolnego odnośnie do nauczania. Odczuwanie tej rozbieżności przez wszystkich zainteresowanych stanowi pierwszy stopień pewnej „obcości” konfesjonalnej nauki religii w publicznej szkole.

\section{Zabezpieczenia prawne}

Ta „obcość” będzie może dla was bardziej zrozumiała, jeśli wyjaśnię, że u nas troska o naukę réligii w szkole nie spoczywa na barkach Kościoła (jak np. w Austrii, w Zachodnim Berlinie czy gdzie indziej). W Republice Federalnej Niemiec organizatorem nauki religii jest państwo, względnie komunalna instytucja, odpowiedzialna za szkolnictwo. One są „przedsiębiorcami” i organizatorami nauki religii. Artykuł 7 naszej konstytucji brzmi:

1. „Całość nauczania szkolnego znajduje się pod nadzorem państwa”.

2. „Decyzja o braniu udziału w nauce religii należy do prawnych opiekunów”. 
3. „Nauka religii w szkołach publicznych... należy do normalnych przedmiotów. Nie naruszając państwowego prawa do nadzoru, religii będzie się nauczać zgodnie z zasadami danego wyznania. Żaden nauczyciel nie może być zobowiązany do nauczania religii wbrew jego woli".

Tekst ten został w r. 1949 przejęty w sposób dosłowny z konstytucji Republiki Weimarskiej z r. 1919. Jeśliby się go chciało dziś zmienić, musiałby być przegłosowany przez większość liczącą $2 / 3$ głosów w parlamencie. Takiej zaś większości, która by mogła lub chciała tego dokonać, nie ma obecnie w politycznej wizji parlamentu.

$\mathrm{Z}$ faktu, że religia jest normalnym przedmiotem nauczania wynika np. to, że nauczyciele religii są kształceni na państwowych uczelniach tak jak inni nauczyciele. Teologia jest tam dziedziną zawodową jak inne dziedziny; nauczyciel religii i profesor teologii są urzędnikami państwowymi.

Nauka religii w szkolnym podziale godziny zajmuje zazwyczaj dwie godziny tygodniowo, i to od klasy I do XIII, niezależnie od rodzaju szkoły. Za książki płaci państwo. Szkolna biblioteka zawiera książki i środki dydaktyczne zarówno dla nauki religii jak i innych przedmiotów. Nota z religii znajduje się na świadectwie, i to tradycyjnie na pierwszym miejscu. Ma wpływ na promocję ucznia, to znaczy w niektórych okolicznościach nota z religii „dobry” lub „,bardzo dobry" może uratować ucznia przed pozostaniem w klasie na rok następny. Państwo opłaca nawet dokształcanie katechetów, które organizuje Kościół.

Mimo to Kościól posiada niczym nie skrępowane prawo do ustalania treści nauki religii. Do Kościoła należy udzielanie zezwolenia na programy i podręczniki zanim one zostaną wprowadzone do użytku. Nauczyciel religii obok zdobytych kwalifikacji państwowych musi jeszcze otrzymać kościelne zlecenie, czyli misję kanoniczną. Misji kanonicznej udziela się tylko wtedy, kiedy składający podanie o nią kandydat podpisze, że będzie nauczał zgodnie z nauką Kościoła, a w życiu osobistym będzie przestrzegał katolickich zasad. Oprócz tego musi podać nazwiska dwóch osób, jak w starożytnym katechumenacie, którzy poręczą wiarygodność jego oświadczeń. Jednym z nich zawsze musi być ktoś z księży. Poza tym zawsze się zasięga opinii o danym kandydacie u jego proboszcza.

W Republice Federalnej Niemiec pracuje obecnie około 60000 nauczycielek i nauczycieli nauki religii; w tej liczbie bardzo niewielu jest księży i sióstr zakonnych. Toteż świeccy teologowie stanowią poważny potencjał wśród nauczycielstwa zajmującego się nauczaniem religii, tak że chyba nigdzie to zjawisko w tej formie nie występuje. (Jeśli w tym tekście posługuję się wyrażeniem „nauczyciel religii”, to aby nie komplikować sprawy, mam na myśli zawsze tę grupę osób świeckich, mężczyzn i kobiet, którzy studiowali teologię lub pedagogikę religijną, a oprócz tego jeszcze jedną lub dwie dziedziny wiedzy. W szkole zaś zajmują się zawodowo także nauczaniem „świeckich” przedmiotów, a więc nie są czynnie zaangażowani w sprawy kościelne). 
Wolność sumienia jest w naszym systemie tak daleko zagwarantowana, że nauczyciel religii, powołując się na konstytucję (art. $7 \mathrm{nr} \mathrm{3,} \mathrm{ostatnie} \mathrm{zdanie),}$ w każdej chwili może odmówić dalszego nauczania religii, nie tracąc przy tym statusu urzędnika państwowego. $\mathrm{Z}$ drugiej zaś strony władza państwowa musi zabronić dalszego nauczania religii temu, kto na przykład przez rozwód i powtórne małżeństwo utracił misję kanoniczną. Kościół ma prawo do wizytowania nauki religii. Nie czyni jednak z tego użytku, ponieważ pamięta wciąż o dawnym nieszczęsnym „duszpasterskim nadzorowaniu szkół”.

Najdrażliwszy punkt prawny polega jednak na czymś innym. Chodzi o rodziców, którzy mogą w każdym czasie wypisać swoje dziecko z nauki religii, a uczniowie po ukończeniu 14 roku życia mogą to czynić sami, ponieważ według prawa uchodzą już od tego momentu za dojrzałych pod względem religijnym. Toteż „normalny przedmiot nauczania” z możliwością wypisania się $\mathrm{z}$ niego (i to jeszcze bez konieczności uzasadnienia) stanowi właściwie jakieś kuriozum. Możliwość wypisania się z nauki religii jest wskazówką, że twórcy konstytucji liczyli się z na wskroś misyjnym, ewangelizacyjnym i kerygmatycznym charakterem konfesyjnej nauki religii. Z drugiej zaś strony nauczyciele nauki religii z powodu tych słusznych możliwości bywają coraz to bardziej z różnych stron naciskani. Jeśli studenci uciekają (o ile są takie możliwości) od wykładów profesora teologii, to on zaczyna się irytować i popada w kryzys własnej tożsamości.

$\mathrm{Z}$ nauczycielem religii dzieje się to samo. Często bywa na przykład szantażowany przy stawianiu na świadectwie ocen z nauki religii. Są co prawda niektóre okolice w Republice Federalnej Niemiec, gdzie wypisanie się z nauki religii (to znaczy brak noty z nauki religii na świadectwie) uchodzi za pewne społeczne piętno. Są jednak i takie szkoły, w których zaraz u progu roku szkolnego wszystkim rozdaje się formularze służące do wypisania się z nauki religii.

Biorąc pod uwagę przeciętną w skali całej RFN, liczba tych wymeldowań $\mathrm{z}$ nauki religii nie jest zbyt wielka (ok. $10 \%$ ), ale wciąż ma tendencję wzrostu. W niektórych środowiskach, a także w szkołach o klimacie antykościelnym, wynosi ona także czasami 50 \% i nawet więcej. Ze względu na to, że od r. 1945 już nie mamy jednolitych terenów pod względem wyznaniowym, szkoła musi stwarzać możliwość katolickiego i ewangelickiego nauczania religii. Co robić jednak, gdy jedna z tych grup zaczyna się kurczyć? Co począć z tymi uczniami, którzy z tego powodu mają tygodniowo dwie godziny wolnego czasu? Ostatnio został trochę zahamowany proces zbyt lekkomyślnego wypisywania się z nauki religii, ponieważ uczniowie, którzy odeszli, muszą teraz zastępczo uczęszczać na naukę etyki lub filozofii. Kościół traktuje to zjawisko z dość mieszanymi uczuciami, gdyż nauczyciele religii dzięki temu zostali poważnie odciążeni od odpowiedzialności, ponieważ decyzja za nauką religii lub przeciw, już nie rozstrzyga się na płaszczyźnie: religia czy coca-cola. 


\section{Wyniki demoskopijne}

W narastającej liczbie wypisywań się z nauki religii, za które nie może oskarżać poszczególnych nauczycieli, może się także wyrażać niechęć uczniów w stosunku do szkoły w ogólności. Pytanie, czy takie przedmioty, jak nauka o społeczeństwie lub historia, gdyby również były przedmiotami, na które by można było uczęszczać lub nie, nie musiałyby w podobny sposób „tracić” uczniów, pozostawmy sprawą otwartą. Gdy Norbert Havers w r. 1972 opublikował wyniki swojej ankiety na temat nauki religii, to zatytułował swoją książkę: Nauka religii - analiza nielubianego przedmiotu. Nauka religii była lubiana jedynie przez tych uczniów, którzy dzięki życiu rodzinnemu i parafialnemu wnosili korzystne usposobienie w stosunku do nauki religii i wiary. Co stanie się jednak z samą nauką religii, jeśli liczba tych uczniów stale się będzie zmniejszać i w końcu spadnie do 10 procent?

W roku 1987 biskupi przeprowadzili sondaż opinii na tematy szkolne wśród nauczycieli religii, rodziców i uczniów. Wyniki wykazały, że nauka religii dla większości uczniów należy do dziedzin, które są dla nich całkiem obojętne, to znaczy nie budzi żadnych emocji, ani „za” ani „przeciw” - po prostu jest ona dla uczniów czymś indyferentnym. Podobne znaczenie ma dla nich nauka o społeczeństwie i historia, podczas gdy matematyka i język niemiecki wywołują już duże zróżnicowanie: obie wyzwalają silny rezonans i to w dwóch przeciwnych kierunkach. U jednej części sprzeciw, a u drugiej emocjonalną aprobatę. Za najbardziej ulubiony przedmiot uchodzi sport.

Dla uczniów, którzy przestali żyć wiarą we wspólnocie kościelnej (nawet, gdy byli ochrzczeni i przystępowali do I Komunii św.), nauka religii w szkole jest jakimś obcym ciałem, i to w tym większym stopniu, im bardziej jest wyznaniowo sprofilowana. Klasyczne treści nauki religii: Biblia, rok kościelny, Credo, modlitwa - nie mają u nich żadnego odniesienia do życia. Oni żyją przecież na co dzień tym, co ich rodzice, czyli brakiem praktyk religijnych, bez przywiązywania jakiegokolwiek znaczenia do wiary. Dzieje się to więc to, że choć nauka religii jest u nas pod względem prawnym doskonale zagwarantowana i nauczyciele są dobrze wykształceni, cały system należycie funkcjonuje to jednak brakuje jej akceptacji wśród adresatów. Jest to oczywiście problem, który występuje nie tylko na tle szkoły. W rzeczywistości zmiejsza się akceptacja kościelnie zdefiniowanej wiary w ogólności w całym naszym społeczeństwie. Chrześcijański system wartości już nie jest akceptowany jako pomoc w życiowej orientacji dla społeczeństwa, które zatraciło wyznaniowy i kościelny charakter. Na tym polega nasz rzeczywisty problem.

W nauce religii dostrzegamy go najłatwiej, ponieważ tutaj najwyraźniejjak nigdzie poza tym w społeczeństwie — Kościół ze swoją misją natrafia na ludzi indyferentnych. Prawie we wszystkich innych dziedzinach życia człowiek może się uchylić od kościelnych przepisów, i to bez jakichkolwiek następstw, 
może za wyjątkiem spraw cmentarnych. W żadnym innym miejscu Kościół nie wchodzi w oficjalny kontakt $\mathrm{z}$ grupami indyferentnymi pod względem wyznaniowym, tak żeby one stanowiły dla niego jakieś wyzwanie (szpital, więzienie, duszpasterstwo wojskowe - stanowią raczej sytuacje podobne do nauki religii w szkole!). W takiej sytuacji Kościół zostaje zmuszony do ograniczania się do duszpasterstwa rdzennej wspólnoty parafialnej, tak jak to już mówiliśmy.

W pytaniu o naukę religii w publicznej szkole zsekularyzowanego społeczeństwa tkwi głębsze pytanie o motywacyjną siłę chrześcijańskiej wiary w tym nowoczesnym, „odkościelnionym” społeczeństwie w ogólności. Dlaczego wiara w Boga i Ewangelia są czymś dobrym? Co się zmienia, jeśli się je traktuje na serio? Jak je przedstawić dzieciom i młodzieży, które nie należą do wspólnot parafialnych, i to tak, żeby to było dla nich zrozumiałe?

Zanim przejdę do dalszego ciągu referatu, chciałbym postawić kilka pytań pobocznych: Czy wolno teologowi tak myśleć i mówić, jak ja to uczyniłem w ostatnich 5 minutach? Czy możemy kierować się wynikami badań demoskopijnych i snuć rozważania na temat ich potrzeby? Czy przez to nie funkcjonalizujemy naszej wiary? Czy nie jest to raczej sprawa socjologów? Czy nie powinien ten, co jest powołany do głoszenia wiary uwolnić się od podobnych rozważań i przekazywać to, co jest mu zadane - importune, opportune?

Na to chciałbym krótko odpowiedzieć, co następuje:

Po pierwsze, wydaje mi się, że takie pytania stawiają sobie przeważnie ci, co stanowią „oficerski sztab” w dziedzinie religijnego nauczania, a nie ci, co znajdują się na froncie nauki religii, ucząc 10 lub 20 godzin tygodniowo. Znam nauczycieli religii, co musieli się poddać badaniom psychosomatycznym w klinikach, ponieważ ich organizm buntował się przeciw codziennemu doświadczeniu braków sukcesów i braków rezonansu ich pracy.

Po drugie, Bóg, któremu oddaliśmy się na służbę, jest „Bogiem ludzi”, który solidaryzuje się z „zagubionymi”, który człowieka ratuje, zbliżając się do niego i przebywając z nim, który ludzi obdarza zaufaniem, zanim jeszcze czegoś dokonali. Zainteresowanie Boga człowiekiem byłoby zakłamane, gdyby nauczyciel religii nie interesował się dyspozycją wiary swoich uczniów i jej nie respektował. Tylko wtedy, kiedy Bóg doświadczany jest jako „Życie ludzi” mamy do czynienia $\mathrm{z}$ wiarą, nie zaś z ideologią.

Po trzecie, chciałbym przypomnieć św. Pawła, który na areopagu (Dz 17), wśród „stojących z dala od wiary” tak próbował wyartykułować prawdy wiary, aby one trafiły do ich horyzontów myślowych w decydującym punkcie, jakim była nauka o zmartwychwstaniu. Napotkał sprzeciw. Musiał to przełknąć. „Paweł odszedł spośród nich” (17,33), ale nauczyciel religii pozostaje przy swoich uczniach dopóty, dopóki oni sami się nie wypiszą z jego nauki. Przez to uwidacznia on coś $\mathrm{z}$ istoty Bożej w miejscu na pozór bez obecności Boga. 


\section{Uzasadnienie szkolno-pedagogiczne}

Okazało się, że stabilne prawo już na niewiele się zdaje, jeśli nauka religii nie znajduje oparcia opinii publicznej. Jeśli ma być ona dalej akceptowana, to nie wystarczą odwoływania się do historii, do konstytucji, do intencji Kościoła i państwa. Raczej trzeba zwracać uwagę na treści, aby wykazać, że człowiek przez religię, wiarę zostaje ubogacony, że jest obdarzony wolnością, jest bardziej krytyczny, szczery, myśli społecznie, czuje się globalnie współodpowiedzialny za wszystko - krótko, że religia i wiara są źródłem siły i zdolności potrzebnych do tego, aby człowiek dorastał do swojego człowieczeństwa. Jeżeli się tego nie będzie czynić, to nauka religii w publicznej szkole będzie coraz bardziej popadać w podejrzenie, że jest przede wszystkim narzędziem Kościoła $\mathrm{w}$ podtrzymywaniu go przy istnieniu przez rekonstrukcję powołań $\mathrm{w}$ formie indokrynacji.

Po raz pierwszy ten rodzaj podejrzenia pod adresem nauki religii pojawił się w „rewolucji kulturalnej” w roku 1968. Pedagogika religijna odpowiedziała na to wówczas w sposób twórczy, co znalazło później odbicie w postanowieniach Wspólnego Synodu Biskupstw Republiki Federalnej Niemiec: Nauka religii w szkole. To postanowienie synodalne zostało w roku 1974 uchwalone imponującą przewagą głosów (233 na 240 głosujących). Wynik tego głosowania odzwierciedla rangę i autorytet tekstu, który odtąd uchodzi za coś w rodzaju Magna Charta w katolickiej nauce religii.

W pierwszej części jest bez ogródek (jak rzadko w kościelnych dokumentach) ukazana trudna sytuacja i nie do utrzymania na dalszą metę tradycyjna nauka religii. „Jeżeli nauczyciel... próbuje nauczać wiary i wprowadzać w życie Kościoła" - jest tam powiedziane (1.1.1) — „to często jest to mowa z niewidomym o kolorach". Część ta kończy się rozróżnieniem pomiędzy katechezą parafialną (np. celem przygotowania dzieci parafii do pierwszej Komunii św.) a nauką religii w szkole, która nie może być utożsamianiem $\mathrm{z}$ katechezą.

W części głównej zostało najpierw podkreślone instytucjonalne zabezpieczenie nauki religii w państwowej szkole. Następnie pojawiają się - i to jest nowością - antropologiczne, historyczno-kulturalne i społeczne uzasadnienia konieczności nauki religii, które mają odniesienie także i do ludzi dystansujących się od Kościoła i do których nie trafiają żadne misjonarskie wysiłki. Zacytuję parę takich zdań: „Żaden człowiek, nawet najbardziej prosty, nie może duchowo żyć, jeśli nie znajdzie odpowiedzi, bądź prymitywnej, bądź bardziej ogólnej na pytanie o sens świata. Tam, gdzie religia mu w tym nie pomoże, ucieka się do wizji, które mu te odpowiedzi mają jakoś zastąpić” (tutaj synod cytuje Pädagogische Antropologie Heinricha Rotha). Religię przedstawia się w szerszym znaczeniu jako tłumaczenie świata albo nadawanie sensu przez odniesienie do transcendencji (2.3). „Treściowo chodzi tutaj o pytania: skąd, dokąd, czemu, dlaczego, o sens i wartość lub bezsens i brak wartości zarówno ca- 
łości, jak części świata, oraz tego, co na świecie. Jest wiele sytuacji w życiu człowieka, które są możliwe do kształtowania przez niego dzięki jego zdolnościom. Życie jednak może się tak skomplikować, że coraz radykalniej i głębiej musi szukać radykalnych odpowiedzi. Sytuacje i doświadczenia, które domagają się wyjaśnienia sensu odnoszą się np. do płodności — rodzenia — śmierci — nadziei - miłości — przyjaźni — przypadku — zaufania — strachu — szczęścia - winy - przebaczenia - troski - niepowodzenia - rozrywki-ekstazy — uniesienia - świętowania itd. (2.3.2). W gruncie rzeczy macie tu do czynienia z nową listą tematów nauki religii. Powinno się unikać w niej nauczania pytań i odpowiedzi wiary, których nikt nie stawia. Wiara chrześcijańska musi się tutaj sprawdzić jako pełna odpowiedź na wyżej postawione pytania. Stąd nie może już być przekazywana jáko zamknięty system. Uczeń, który został oczarowany przez świat techniki, tworzenie i konsumowanie, wyczulony na rzeczy praktyczne, musi być uwrażliwiony przede wszystkim na wszystkie zagrożenia stąd wypływające. Nauka religii musi w takiej sytuacji raczej inspirować i uwrażliwiać niż przekazywać pakiet wiedzy tudzież doprowadzać do kościelnej socjalizacji.

Zgodnie z postanowieniem synodu ,zadanie nauczania religii” należy do szkoły:

- ponieważ szkoła powinna młodzież zaznajamiać i oswajać z bogactwem duchowej kultury, która kształtuje naszą sytuację, i ponieważ chrześcijaństwo wraz ze swoimi wyznaniami należy do naszego kulturalnego dziedzictwa;

- ponieważ szkoła powinna pomóc młodemu człowiekowi do ukształ towania jego osobowości, a nauka religii przez odpowiedź na pytania o sens i zasady pomaga mu odnaleźć jego rolę i zadanie w społeczeństwie, przystosować się do życia i we właściwej perspektywie je widzieć;

- ponieważ szkoła nie może zadawalać się jedynie dopasowywaniem ucznia do obecnych urządzeń świata, dlatego nauka religii jest nastawiona na relatywizację niesprawiedliwych wymagań, na protesty przeciw sprzecznościom i na czyny prowadzące do korzystnych zmian.

„Każdy z tych trzech argumentacyjnych wniosków ma swoją specyficzną wagę. Jeśli się je razem zespoli, wynika $\mathrm{z}$ tego konieczność nauki religii w publicznej szkole" (2.3.4). Tu jednak pojawia się bardzo blisko krytyczne pytanie poboczne: czy przez tę próbę dalszego uzasadnienia konieczności nauki religii przez zmianę roli religii w życiu ucznia, nie powracamy znowu do tego, co charakteryzowało naukę religii w okresie Oświecenia. Należy jednak zauważyć, że zawsze religia i wiara są wymieniane równocześnie: „Nauka religii ma uzdoInić do odpowiedzialnego myślenia i postępowania w odniesieniu do religii i wiary" (2.5.1).

Tak brzmi pierwsze zdanie zawarte w ustępie dotyczącym celu nauczania religii. W nauce religii nie stawia się tu bez uwarunkowań pytań o religię, ale 
zawsze w oparciu o zreflektowaną chrześcijańską Tradycję. W ten sposób następuje po cytowanym już religijno-antropologicznym uzasadnieniu (2.3) teologiczne uzasadnienie dla tak pojętego pedagogicznego punktu widzenia (2.4). Przez to teologia, bazując na nauce religii, staje się otwarta na świat, jest powiązana ze społeczeństwem i orientuje się na człowieka. Chodzi o teologię, która zobowiązana jest do tak zwanego antropologicznego zwrotu. Wynika z tego korelacja wiary z życiem: „Wiara ma być rozwijana w kontekście życia, a życie powinno być pojmowane w kontekście wiary”. Wynikają z tego także konsekwencje praktyczne: „Ponieważ Ewangelia oznacza wyzwolenie, mimo naglącej powagi Orędzia, przekaz wiary nie może podlegać dalszym manipulacjom”. Albo: „wynika z tego, że także oceny z nauki religii muszą być niezależne od stanowiska wiary ucznia".

Cele na ogół są obecnie skromniej sformułowane niż przedtem. Jest nawet powiedziane (2.6.5), że szkolna nauka religii już wtedy „opłaca się” dla Kościoła, „gdy uczniowie po opuszczeniu szkoły nie traktują religii i wiary jako czegoś zbytecznego lub całkiem bezsensownego; i jeśli oni religię i wiarę traktują jako możliwość ubogacenia człowieka, jako możliwą siłę służącą rozwojowi jego Osobowości i jako inspirację do realizowania wolności”. Przez to jednak nie zostają wyrzucone poza nawias tradycyjne tematy wiary od Trójcy św. po sakrament spowiedzi. Niemniej jednak dodano kryteria, od których zależy atrakcyjny sposób podania tych treści.

Konfesjonalność nauki religii jest w zasadzie uznawana, ale pod warunkiem, że w niczym nie narusza wolności innych wyznań czy poglądów. Nauczyciel religii powinien wiedzieć, że religia jest dla niego nie tylko przedmiotem, lecz także miejscem nauczania. Jego związek z Kościołem nie musi oznaczać konieczności ukazywania obrazu tej instytucji w idealnym świetle. „Miłość do Kościoła i krytyczny dystans nie muszą się wzajemnie wykluczać" (2.8.5).

Ten punkt widzenia jest przez nauczycieli religii odczuwany jako wyswobadzający, godny i stabilny. Funkcjonuje więc w dalszym ciągu bez ograniczeń. I chyba nie przypadkowo pojawiło się pytanie, czy istnieje możliwość wymeldowania się z uczęszczania na tak pojętą naukę religii. (Oficjalnie oczywiście nikt tej sprawy nie porusza, bo wtedy w centrum politycznej dyskusji musiałby się znaleźć cały 7. artykuł Konstytucji).

\section{Diakonalna nauka religii}

Wyżej naszkicowany typ nauki religii przyjął się u nas w praktyce. Jeśli ktoś spróbuje spojrzeć na podręczniki do nauki religii, które otrzymały kościelną i państwową aprobatę (gdy chodzi o samą katolicką naukę religii, to nauczyciel ma możliwość wyboru pomiędzy 10 podręcznikami dla szkoły podstawowej), to jest zdziwiony bogactwem ich różności, zabarwienia i rozbieżności w odnie- 
sieniu do tematyki nauczania. Odznaczają się także siłą impulsywną jak i zrozumieniem realiów. Są, jak nigdy dotąd, nasycone przyjaźnią w stosunku do ucznia. Ceną tak wielkiego zbliżenia się do problemów życia codziennego jest niezwykle mała przejrzystość nauki religii. To spowodowało, że ostatnimi laty znów zaczęto się z niepokojem pytać o spójność nauczania tego przedmiotu. Nauczanie według ,zaplanowanego obszaru celów” z roku 1973 zostało w roku 1984 zastąpione „planem podstawowym”, zawierającym kanon tematów obowiązkowych. Tutaj tematyka doświadczenia i tematyka orędzia zbawczego są ze sobą powiązane w sposób bardziej uporządkowany, czyli odpowiadają zasadniczemu postulatowi, jakim jest korelacja pomiędzy doświadczeniem i wiarą.

Wszystkie wszakże próby wprowadzenia nauki religii na tory katechizmowego rygoryzmu, jak dotąd, zawsze kończyły się niepowodzeniem. Taki sposób przekazu wiedzy religijnéj musi bowiem zakładać istnienie homogenicznego społeczeństwa, w którym problematyka wiary jest przedmiotem bezpośrednich zainteresowań i znajduje odbicie w życiu. W tym kontekście wciąż powracające narzekania, że na religii za mało się uczy pytań i odpowiedzi, jest bezprzedmiotowe. Jeśli bowiem by się chciało, aby wyuczony material został utrwalony, musiałby on w środowisku ludzi dorosłych, w którym uczeń żyje, coś znaczyć, ale tak nie jest. Srodowisko to nie żyje wiarą. Byłoby jednak wyrazem, moim zdaniem, ogromnej krótkowzroczności posądzanie nauki religii o ten brak wiary. Toteż nawet i najbardziej zaangażowany nauczyciel religii jest bezradny, gdy się mu postawi pytanie o to, co jego nauka religii wnosi do aktywnego uczestnictwa uczniów w życiu kościelno-sakramentalnym. Zawarty w tym pytaniu cel nauki religii przekracza jej możliwości. Wszystkie dane z empirycznych badań dowodzą, że optymalna socjalizacja religijna zakłada daleko idące kongruencje między domem, szkołą, Kościołem, jak również i wsparcie dodatkowe, np. środowisko towarzyskie. Tego rodzaju założenia istnieją przeważnie w próżni. Ankieta z Allensbach, przeprowadzona w r. 1987 wskazuje nawet, że rodzice, żyjąc w wciąż narastającym wyobcowaniu z Kościoła i religii, nie oczekują od nauki religii umocnienia wiary czy uzasadnienia religijnych zobowiązań, lecz żądają społecznie pożądanych postaw. O postawach tych decyduje panujący społeczny konsens, w myśl którego nauka religii ma uczyć dostrzegania innych, rozwijać tolerancję, przekazywać etyczną wiedzę i społecznie angażować.

Za przygotowaniem do praktyk religijnych przez naukę religii opowiedziała się tylko mniejszość respondentów wspomnianej ankiety. Im słabsza była motywacja religijna rodziców, tym bardziej z ich strony preferowano aspekty o charakterze świeckim (naukę religii jako narzędzie przekazu społecznie pożądanych postaw). Nauczyciele religii ze swej strony reprezentowali przeważnie stanowisko odpowiadające uchwałom ich nadzwyczajnego zjazdu. Nie pozwolili się przykuć do alternatywy: „przepowiadanie albo niesienie pomocy życiowej". 
Za główne zadanie uznali wzajemne przenikanie się tych zagadnień w warunkach dzisiejszego społeczeństwa. Zarówno nauczyciele jak i uczniowie zwrócili się w kierunku poszukiwań odpowiedzi na pytanie o sens tego, co ogólne, i tego, co szczegółowe, o szukanie tego, co wartościowe w szczęściu i cierpieniu. Zaczęto zwracać większą uwagę na aspekty transcendentne w życiu każdego człowieka. Wszystko, jak z tego widać, może stać się tematem nauki religii, jeżeli tylko pytania zawierają odpowiedni ładunek aktualności, tak aby mógł przeniknąć zamknięty horyzont zawężonych faktów, potrzeb i celów. Takie poszerzenie horyzontów myślenia wychodzi naprzeciw postulatom wiary i domaga się ich aktualizacji. Wypływają z tego oczywiście liczne korzyści zarówno dla uczniów, jak i dla szkoły.

Na tym tle pojawia się jeszcze jedno pytanie: czy Kościół z takiego ukierunkowania nauki religii będzie mógł czerpać jakieś owoce, a w konsekwencji, czy będzie się mógł za nią opowiadać? A może przeciwnie - przestanie go interesować tak pojęta nauka religii?

Dla $80-90 \%$ uczniów szkolna nauka religii to ostateczny pomost pomiędzy nimi a Kościołem (por. F. W. Niehl: „Katechetische Blätter” 3:1989 i następne zawarte tam zagadnienia). Tylko dzięki nauczycielowi religii młodzi ludzie doświadczają czegoś, co może jeszcze mieć jakieś znaczenie dla ich wiary. Ponadto nauka religii stanowi bardzo istotne miejsce na terenie szkoły, gdy się weźmie pod uwagę dzisiejsze postawy i sposób myślenia współczesnego człowieka. Tutaj musi się sprawdzić, czy teologiczne wypowiedzi na temat wiary i etyki mogą zostać przybliżone człowiekowi, który w swoim myśleniu i mowie daleki jest od chrześcijaństwa.

Konieczność zrozumienia przekazu orędzia zbawczego przez ludzi znajdujących się poza zasięgiem oddziaływania Kościoła wymaga na nowo przemyślenia języka wiary, Nauka religii stoi przed wyzwaniem, jakim jest nieobecność wiary w kulturze i społeczeństwie. Wiara osłabiwszy swoje związki ze światem, kulturą, literaturą, muzyką, traci także swoje kompetencje w problematyce społecznej.

Mając na uwadze ten stan rzeczy, powiem krótko: u nas dziś coraz to większe znaczenie ma ten aspekt nauki religii, w którym się wyraża jej funkcja diakonalna. Synodalne postanowienie mówi na ten temat: Do Kościoła, który powołuje się na Jezusa Chrystusa, należy jako jemu najwłaściwsze zadanie „być dla innych". Niezależnie od tego, czy ludzie doń formalnie należą, czy nie, musi być on zawsze gotowy do służenia innym właśnie tym, czym on jest i do czego jest powołany. Nauka religii w szkole jest jedną z tych form, w których Kościół może pełnić swoją służbę wobec młodych ludzi. I w tym sensie trzeba patrzeć na jej charakter diakonalny. Kładzenie nacisku na diakonię zawsze stoi wobec podejrzenia o ,horyzontalizm” i sekularyzm.

Diakonalna nauka religii jest podejrzana o zatrzymywanie się na przedpolu i na tym, co nie jest dla niej istotne. Jednakże trzy podstawowe funkcje Kościo- 
ła - martyria, liturgia, diakonia $-\mathrm{z}$ teologicznego punktu widzenia mają jednakową wagę i znaczenie. Jest więc błędem w oparciu o powyższe wyliczanie przyznawać diakonii jedynie miejsce trzecie. Diakonia stanowi bowiem szczególną formę martyrii: jest bezgłośną mową, która wypływa z przelgnięcia do chrześcijańskiego ducha.

Nauka religii w publicznej szkole w zsekularyzowanym społeczeństwie może mieć przyszłość tylko wtedy, kiedy będziemy mogli uwiarygodnić, że nie chodzi w niej o sam Kościół, lecz o człowieka w jego pełnym wymiarze, i że wiara chrześcijan jest w stanie nieść ludziom pomoc i zbawienie.

Ttumaczyt ks. Marian Jakubiec 